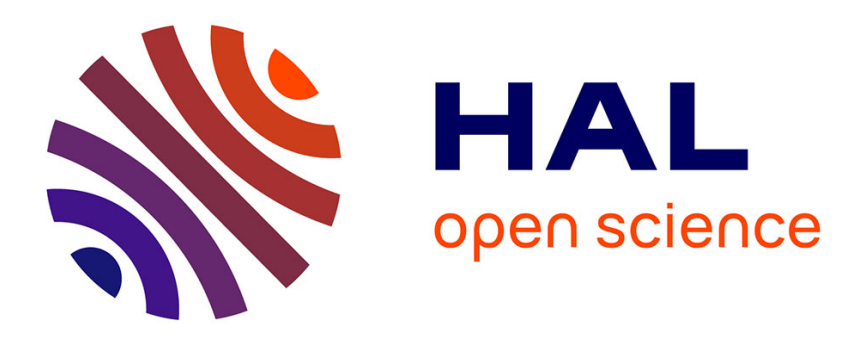

\title{
Molybdenum Open-Shell Organometallics. Spin State Changes and Pairing Energy Effects
}

\author{
Rinaldo Poli
}

\section{To cite this version:}

Rinaldo Poli. Molybdenum Open-Shell Organometallics. Spin State Changes and Pairing Energy Effects. Accounts of Chemical Research, 1997, 30 (12), pp.494-501. 10.1021/ar960280g . hal-03313697

\section{HAL Id: hal-03313697 \\ https://hal.science/hal-03313697}

Submitted on 8 Oct 2021

HAL is a multi-disciplinary open access archive for the deposit and dissemination of scientific research documents, whether they are published or not. The documents may come from teaching and research institutions in France or abroad, or from public or private research centers.
L'archive ouverte pluridisciplinaire HAL, est destinée au dépôt et à la diffusion de documents scientifiques de niveau recherche, publiés ou non, émanant des établissements d'enseignement et de recherche français ou étrangers, des laboratoires publics ou privés. 
Molybdenum Open-Shell Organometallics. Spin State Changes and Pairing Energy Effects

\author{
RINALDO POLI* \\ Laboratoire de Synthèse et d'Électrosynthèse \\ Organométallique, Université de Bourgogne, \\ Faculté des Sciences "Gabriel", 6, Boulevard Gabrie, \\ 21100 Dijon, France
}

Received December 20, 1996

\section{Introduction}

About 8 years ago, we started an investigation of halfsandwich paramagnetic (17-electron) Mo(III) complexes of type (ring) $\mathrm{MoX}_{2} \mathrm{~L}_{2}$ (ring $=\mathrm{Cp}, \mathrm{Cp} *$; $\mathrm{L}=$ tertiary phosphine; $X=$ halide), the first examples of which had been briefly described earlier by M. L. H. Green and coworkers. ${ }^{1}$ These are stable organometallic radicals, and our underlying interest was the hope to couple the affinity for binding $\pi$-acceptor ligands of potential use in organometallic synthesis and catalysis with the higher lability that had up to that point been established for lower-valent radicals with respect to analogous saturated systems. ${ }^{2}$ The ability of this particular system to bind and thus hopefully activate the $\pi$ ligand is demonstrated by the existence of allyl complexes, i.e. $\mathrm{CpMo}\left(\eta^{3}-\mathrm{C}_{3} \mathrm{H}_{5}\right)_{2}{ }^{3,4}$ and diene complexes, e.g. $\mathrm{CpMoCl}_{2}\left(\eta^{4}-\mathrm{C}_{4} \mathrm{H}_{6}\right)^{5}{ }^{5,6}$ There was hope, therefore, to extend this class to other interesting organic substrates and to find new or perhaps simply plain old but kinetically enhanced reactivity. We soon realized, however, that these compounds have a very different behavior from that of lower-valent systems with the same electron count and in many respects they more closely resemble Werner-type complexes. We came to the appreciation that the general class of open-shell organometallics can be understood as a hybrid of the two classes of coordination compounds at the two opposite extremes of the bonding scale: low-valent organometallics on one side and Werner-type complexes on the other. Therefore, a rationalization of the chemical behavior of these materials must be sought in the fundamental principles that regulate the chemical behavior at both extremes, and linear combinations thereof. A general discussion of these underlying principles, such as the pairing energy stabilization, and of the effects of a spin state change on the

Rinaldo Poli was born in Barga, Italy, on August 17, 1956. He has received the Laurea degree from the University of Pisa in 1981 and the Perfezionamento degree from the Scuola Normale Superiore, Pisa, in 1985, under the direction of Fausto Calderazzo. During this time, he had a 1-year experience as exchange student with G. Wilkinson at Imperial College (1982-83). He also received the title of Dottore di Ricerca from the Italian Ministery of Education in 1988. After a postdoctoral position with F. A. Cotton at Texas A\&M in 1985-87, he joined the faculty at the University of $M$ aryland at College Park, where he rose through the ranks to become Professor of Chemistry in 1995. In 1996, he returned to Europe to occupy a Professor position at the Universite de Bourgogne. stability, reactivity, and structure of organometallic compounds is presented in a review that I recently published in Chemical Reviews. ${ }^{7}$ The focus of this Account will be the development of our thinking while investigating openshell organometallics of Mo and more recently also of $\mathrm{Cr}$.

\section{Halide Exchange on the 17-Electron $\mathrm{CpMOX}_{2} \mathrm{~L}_{2}$ System}

We started with the desire to verify the kinetic lability of the $\mathrm{CpMoX}_{2} \mathrm{~L}_{2}$ system and, for that purpose, synthesized a variety of derivatives with different halide and phosphine ligands for ligand exchange kinetic studies. ${ }^{8-11}$ Figure 1 shows the ubiquitous ${ }^{12}$ four-legged piano-stool geometry of a representative example, $\mathrm{CpMoCl} 2\left(\mathrm{PMe}_{3}\right)_{2} .{ }^{11}$ We initially elected to investigate the halide ligand exchange on the $\mathrm{CpMoX}_{2}\left(\mathrm{PMe}_{3}\right)_{2}$ system, more precisely the $\mathrm{CpMol}_{2}-$ $\left(\mathrm{PMe}_{3}\right)_{2} / \mathrm{Cl}^{-}$system (eq 1 ), because this is sufficiently slow and the resonances of the starting compound, product, and mixed-halide intermediate are sufficiently separated for monitoring by EPR spectroscopy.

$$
\begin{aligned}
& \mathrm{CpMol}_{2}\left(\mathrm{PMe}_{3}\right)_{2}+2 \mathrm{Cl}^{-} \rightarrow \\
& \mathrm{CpMoClI}\left(\mathrm{PMe}_{3}\right)_{2}+\mathrm{Cl}^{-}+\mathrm{I}^{-} \rightarrow \\
& \mathrm{CpMoCl}_{2}\left(\mathrm{PMe}_{3}\right)_{2}+2 \mathrm{I}^{-}
\end{aligned}
$$

It was initially difficult to gather accurate kinetic data because trace amounts of the oxidized material, the 16electron $\mathrm{Mo}(\mathrm{IV})$ cations $\left[\mathrm{CpMoX}_{2}\left(\mathrm{PMe}_{3}\right)_{2}\right]^{+}$, catalyze the exchange process in a way that is interesting in its own right and will be examined later. Accurate results were eventually obtained and showed two competing secondorder pathways, the nucleophiles being free $\mathrm{Cl}^{-}$and ionpaired $\mathrm{PPN}^{+} \mathrm{Cl}^{-}$, respectively, inconsistent with a dissociative mechanism. An Eyring analysis on the $\mathrm{Cl}^{-}$path yields a large negative activation entropy, $\Delta S_{i}^{\psi_{i}}=-26.0 \pm$ $5.7 \mathrm{cal} \cdot \mathrm{mol}^{-1} \cdot \mathrm{K}^{-1}$, favoring an associative or ring slippage mechanism. ${ }^{13-15}$ The subsequent discovery that the analogous C $p^{*}$ system is 5 orders of magnitude faster rules out a pure associative mechanism though 19-electron intermediates (at least for the Cp* system). This was initially

*Telephone/FAX: 011-33-380396881. E-mail: Rinaldo.Poli@u-bourgogne.fr.

(1) Grebenik, P. D.; Green, M. L. H.; Izquierdo, A.; Mtetwa, V. S. B.; Prout K. J. Chem. Soc., Dalton Trans. 1987, 9-19.

(2) Organometallic radical processes; Trogler, W. C., Ed.; Elsevier: Amsterdam, 1990; Vol. 22.

(3) Jolly, P. W.; Krüger, C.; Romão, C. C.; Romão, M. J. Organometallics 1984, 3, 936-937.

(4) Andell, O.; Goddard, R.; Holle, S.; Jolly, P. W.; Krüger, C.; Tsay, Y. H. Polyhedron 1989, 8, 203-209.

(5) Davidson, J. L.; Davidson, K.; Lindsell, W. E.; Murrall, N. W.; Welch, A. J. J. Chem. Soc., Dalton Trans. 1986, 1677-1688.

(6) Davidson, J. L.; Davidson, K.; Lindsell, W. E. J. Chem. Soc., Chem Commun. 1983, 452-453.

(7) Poli, R. Chem. Rev. 1996, 96, 2135-2204.

(8) Krueger, S. T.; Poli, R.; Rheingold, A. L.; Staley, D. L. Inorg. Chem. 1989, 28, 4599-4607.

(9) Krueger, S. T.; Owens, B. E.; Poli, R. Inorg. Chem. 1990, 29, 20012006.

(10) Linck, R. G.; Owens, B. E.; Poli, R.; Rheingold, A. L. Gazz. Chim. Ital 1991, 121, 163-168.

(11) Poli, R.; Owens, B. E.; Krueger, S. T.; Rheingold, A. L. Polyhedron 1992 11, 2301-2312.

(12) Poli, R. J. Coord. Chem. B 1993, 29, 121-173.

(13) Wojcicki, A.; Basolo, F. J. Inorg. Nud. Chem. 1961, 17, 77-83.

(14) O'Connor, J. M.; Casey, C. P. Chem. Rev. 1987, 87, 307-318.

(15) Basolo, F. Polyhedron 1990, 9, 1503-1535. 


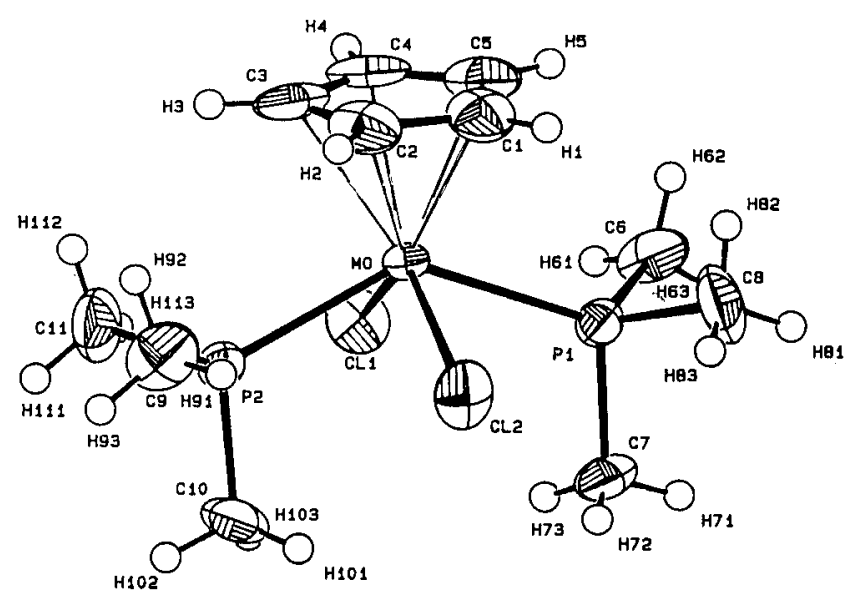

FIGURE 1. Four-legged piano-stool geometry of the $\mathrm{CpMoCl}_{2}\left(\mathrm{PMe}_{3}\right)_{2}$ compound. Reprinted from ref 8. Copyright 1989 American Chemical Society. The same geometry is also observed for $\mathrm{CpMo}(\mathrm{Cl})(\mathrm{I})\left(\mathrm{PMe}_{3}\right)_{2}$, $\mathrm{CpMol}_{2}\left(\mathrm{PMe}_{3}\right)_{2}, \mathrm{CpMoBr}_{2}$ (dppe), $\mathrm{CpMoCl}_{2}\left(\mathrm{PEt}_{3}\right)_{2}, \mathrm{CpMoCl}_{2}\left(\mathrm{PMePh}_{2}\right)_{2}$, and $\mathrm{CPMOCl}_{2}\left(\mathrm{PPh}_{3}\right)_{2},{ }^{11,21}$

considered surprising because lower-valent organometallic radicals typically undergo rapid ligand substitution reactions via 19-electron intermediates or transition states. ${ }^{16}$ Efforts to probe the ring slippage mechanism through the study of analogous indenyl systems were thwarted by synthetic difficulties. ${ }^{17}$ A way to produce pure materials has not yet been found.

In view of later studies discussed below, it is likely that the $\mathrm{Cp}$ system is associative while the $\mathrm{Cp*}$ system is assisted by partial dissociation of the Cp* ring to a slipped 15-electron intermediate. Possible reasons for the involvement of a 15-electron (formally dissociative) intermediate are (a) unfavorable steric crowding, (b) energetically less accessible HOMO relative to lower-valent organometallic radicals (the complexes can be easily oxidized but not reduced), ${ }^{8-11}$ and (c) energetic stabilization of a dissociative intermediate by adopting a high-spin $(S=3 / 2)$ configuration, analogous to stable $\mathrm{CpCr}$ (III) systems. ${ }^{18-20}$

\section{Phosphine Exchange on the 17-Electron CpMoX $\mathrm{L}_{2}$ System}

The relative stability of the phosphine adducts goes in the order $\mathrm{PPh}_{3}<\mathrm{PMePh}_{2}<\mathrm{PEt}_{3} \approx \mathrm{dppe} \approx \mathrm{PMe}_{2} \mathrm{Ph}<\mathrm{PMe}_{3}{ }^{11}$ Qualitative rate experiments seem in agreement with the formation of 15-electron $\mathrm{CpMoCl}_{2} \mathrm{~L}$ intermediates. The evidence is as follows: compounds with larger phosphines, i.e., longer and weaker Mo-P bonds, exchange the fastest, and the self-exchange of $\mathrm{PMe}_{3}$ in $\mathrm{CpMoCl}_{2}-$ $\left(\mathrm{PMe}_{3}\right)_{2}$ is 2 orders of magnitude slower than the same process on the corresponding Cp* system. ${ }^{21}$ The kinetic studies of these two self-exchanges (eq 2 , ring $=\mathrm{Cp}$ or

$$
\begin{aligned}
\text { (ring) } \mathrm{MoCl}_{2}\left(\mathrm{PMe}_{3}\right)_{2}+\mathrm{PMe}_{3}-\mathrm{d}_{9}(\text { excess }) & \rightarrow \\
& \left(\text { ring) } \mathrm{MoCl}_{2}\left(\mathrm{PMe}_{3}-\mathrm{d}_{9}\right)_{2}+2 \mathrm{PMe}_{3}\right.
\end{aligned}
$$

(16) Trogler, W. C. See ref 2, p 306 and references therein.

(17) Poli, R.; Mattamana, S. P.; Falvello, L. R. Gazz. Chim. Ital. 1992, 122, 315-319.

(18) Fischer, E. O.; Ulm, K.; Kuzel, P. Z. Anorg. Allg. Chem. 1963, 319, 253-265.

(19) Grohmann, A.; Köhler, F. H.; Müller, G.; Zeh, H. Chem. Ber. 1989, $122,897-899$

(20) Theopold, K. H. Acc. Chem. Res. 1990, 23, 263-270.
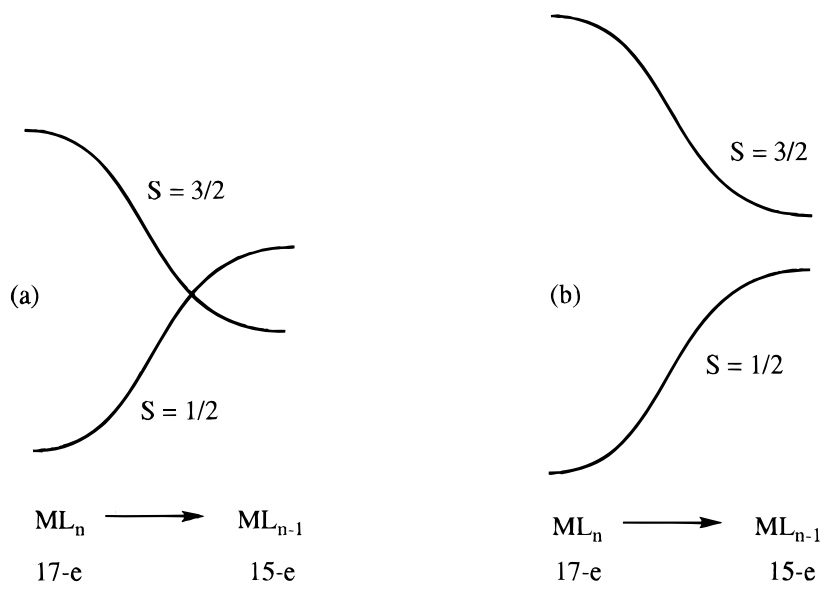

FIGURE 2. Qualitative reaction coordinate for a dissociative process on a 17-electron complex, where the 15-electron intermediate has (a) a spin quartet ground state or (b) a spin doublet ground state.

$\mathrm{Cp} *$ ) indicate an essentially pure first-order process for the $\mathrm{Cp}^{*}$ system and competing first- and second-order processes for the $\mathrm{Cp}$ system. ${ }^{21}$ Thus, only for the most tightly bonded $\mathrm{PMe}_{3}$ ligand in the sterically less encumbered $\mathrm{Cp}$ system is dissociation sufficiently unfavorable to allow the slow associative process to compete.

In conclusion, although low-valent organometallic radicals prefer to exchange ligands associatively through 19-electron intermediates, the 17-electron Mo(III) complexes discussed here prefer to involve 15-electron intermediates. This preference may be linked to the similarity of the proposed intermediates to the Werner-type Mo(III) systems and to the stable 15-electron $\mathrm{CpCr}$ (III) systems. It is therefore likely that these intermediates have a spin quartet ground state and that the spin change contributes significantly to their stabilization. On the basis of the above hypothesis, we have advanced (probably for the first time) the proposal ${ }^{21}$ that a spin state change would, seemingly paradoxically, accelerate a dissociative process (Figure $2 \mathrm{a}$ ) relative to one where the same bond is broken without a spin state change (Figure $2 b)$. This occurs via the thermodynamic stabilization of the reaction intermediate by the spin state change. Conventional wisdom, on the other hand, always sees a spin state change as a kinetically retarding effect. Other previously reported rapid exchange processes might be reinterpretable under this new light. ${ }^{7}$

\section{Thermodynamic Instability of 15-Electron CpMoX 2 L Complexes}

At this point, we were naturally interested in isolating a Mo(III) complex with a 15-electron configuration, analogous to the known $\mathrm{Cr}$ (III) systems, and in determining its magnetic properties. We thought of employing bulky ligands ( $\mathrm{Cp}^{*}$ and large phosphine ligands) to render a 17electron bis-phosphine adduct energetically disfavored with respect to a 15-electron monoadduct. This strategy is successful, for instance, for the synthesis of unsaturated $\mathrm{Mo}(\mathrm{IV})$ and $\mathrm{Mo}$ (II) complexes (vide infra). Unfortunately, 15-electron Mo(III) derivatives could not be stabilized and isolated because of an interesting ligand redistribution

(21) Cole, A. A.; Fettinger, J. C.; Keogh, D. W.; Poli, R. Inorg. Chim. Acta 1995, 240, 355-366. 

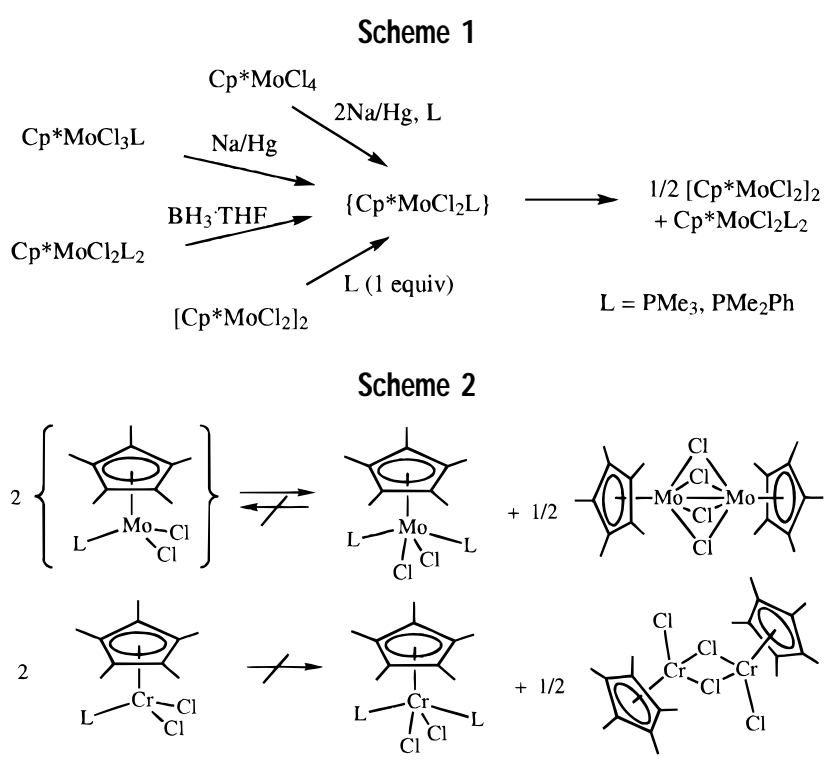

process (see Scheme 1). I dentical results are also obtained for the corresponding $\mathrm{Cp}$ systems. ${ }^{22}$

The results shown in Scheme 1 strongly suggest that the hypothetical $\mathrm{Cp} * \mathrm{MoCl}_{2} \mathrm{~L}$ system is thermodynamically unstable relative to a 1:1 mixture of the 17-electron bisphosphine adduct, $\mathrm{Cp} * \mathrm{MoCl}_{2} \mathrm{~L}_{2}$, and the phosphine-free dimer $\mathrm{Cp}_{2} \mathrm{Mo}_{2} \mathrm{Cl}_{4}$. Of course, this instability does not preclude the involvement as intermediate in the ligand exchange processes discussed above. When the phosphine is too bulky (e.g., $\mathrm{PMePh}_{2}, \mathrm{PPh}_{3}$ ), the 17-electron Cp* product does not form and the only products obtained by reduction of $\mathrm{Cp}^{*} \mathrm{MoCl}_{3} \mathrm{~L}$ or $\mathrm{Cp}^{*} \mathrm{MoCl}_{4} / \mathrm{L}$ are $\mathrm{Cp}_{2}{ }_{2}$ $\mathrm{MO}_{2} \mathrm{Cl}_{4}$ and free $\mathrm{L}$.

It is useful to compare the hypothetical ligand redistribution equilibria for the $\mathrm{Mo}(\mathrm{III})$ and $\mathrm{Cr}(\mathrm{III})$ systems shown in Scheme 2. The putative stabilization of the 15electron Mo(III) system by the spin quartet ground state is apparently not sufficient to overcome the stabilization of the reaction products by the greater number of metalligand bonds and also a Mo-Mo bond. For the $\mathrm{Cr}(\mathrm{III})$ system, on the other hand, the 15-electron system is stable and has no tendency to rearrange. Ligand adducts with a 17-electron configuration are not known, whereas the $\left[\mathrm{Cp} * \mathrm{CrCl}_{2}\right]_{2}$ compound exists but adopts a geometry based on the 15-electron 3-legged piano stool with two antiferromagnetically coupled $\mathrm{S}=3 / 2 \mathrm{Cr}(\mathrm{III})$ centers. ${ }^{23}$ As we have discussed elsewhere, ${ }^{7}$ this difference cannot be solely attributed to the different metal size and $M-L$ bond strengths. The greater stabilization of the lower electronic configuration for $\mathrm{Cr}(\mathrm{III})$ is related to the expected greater energetic advantage for this metal in keeping the electrons unpaired.

\section{A Theoretical Excursion. Total Energies for the $\mathrm{CpMCl}_{2}\left(\mathrm{PH}_{3}\right)+\mathrm{PH}_{3}$ System}

If you cannot make it, you can always compute it. We have therefore carried out total geometry optimizations at various levels of theory on the model systems $\mathrm{CpMCl}_{2}$

(22) Abugideiri, F.; Keogh, D. W.; Kraatz, H.-B.; Poli, R.; Pearson, W. J. Organomet. Chem. 1995, 488, 29-38.

(23) Köhler, F. H.; Lachmann, J.; Müller, G.; Zeh, H.; Brunner, H.; Pfauntsch, J.; Wachter, J. J. Organomet. Chem. 1989, 365, C15.
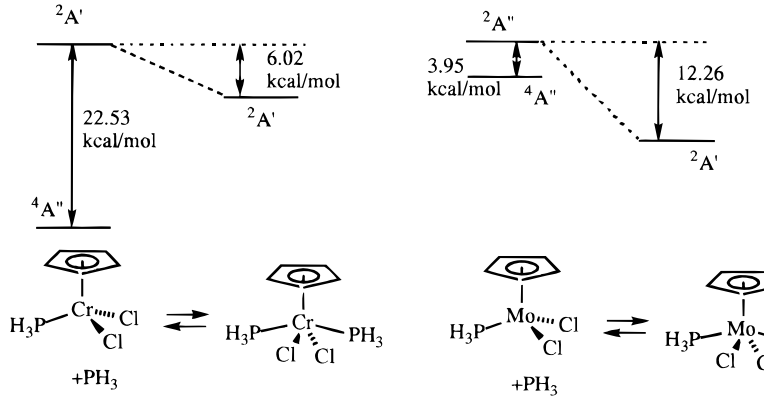

FIGURE 3. Relative total energies for BLYP-geometry-optimized $\mathrm{CPMCl}_{2}$ $\left(\mathrm{PH}_{3}\right)+\mathrm{PH}_{3}$ and $\mathrm{CpMCl}_{2}\left(\mathrm{PH}_{3}\right)_{2}$ systems $(\mathrm{M}=\mathrm{Cr}, \mathrm{Mo})$.

$\left(\mathrm{PH}_{3}\right)_{n}(\mathrm{n}=1$ and 2$)$ for $\mathrm{M}=\mathrm{Cr}$ and Mo. The results are shown in Figure 3 for the BLYP optimizations. These calculations are in good qualitative agreement with the experimental evidence, in that $\mathrm{Cr}(\mathrm{III})$ is most stable as a spin quartet 15-electron system, whereas Mo(III) prefers a spin doublet 17-electron structure. The dominating factor in determining this difference, as expected, is the much larger pairing energy for the smaller $3 d$ orbitals of $\mathrm{Cr}^{24}$ Qualitatively similar results are also obtained at the MP2 level, although the relative energy differences are larger in that case. ${ }^{7}$ Whether the actual numbers are better for the MP2 or the BLYP method is at the center of current heated discussions among theoreticians, but for our purposes, we are just happy to see that both methods yield the same qualitative trends of stability. Both methods also predict that the hypothetical 15-electron $\mathrm{CpMoCl}_{2}$ $\left(\mathrm{PH}_{3}\right)$ system should have a spin quartet ground state. Thus, the calculations give support to the idea that a dissociative ligand exchange for (ring) $\mathrm{MoCl}_{2} \mathrm{~L}_{2}$ could be kinetically helped by the spin state change.

\section{Reactivity of 15-Electron Cationic Mo(III) Complexes}

When we consider the rearrangement of neutral 15electron $\mathrm{CpM} \mathrm{OX}_{2} \mathrm{~L}$ complexes shown in Scheme 2, we are immediately drawn to think of possible ways to prevent it. One way that we have considered is to make the system charged, introducing Coulombic repulsive effects. A negatively charged target molecule could be $\left[(\text { ring }) \mathrm{MoCl}_{3}\right]^{-}$. However, we found that the reaction of the dinuclear precursors [(ring) $\left.\mathrm{MoCl}_{2}\right]_{2}$ with $\mathrm{Cl}^{-}$stops at the formation of the interesting chloro-bridged, triply bonded dimers (see eq 3 for ring $=\mathrm{Cp}$ ). ${ }^{25}$ M ore examples of this system have been reported by Malcolm Green for both Mo and W. ${ }^{26}$

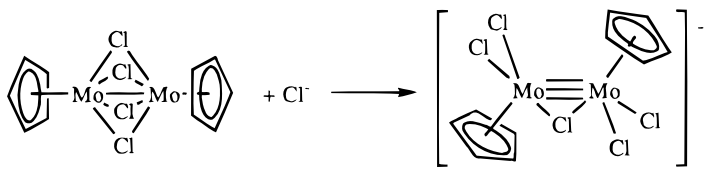

The generation of positively charged complexes, [(ring)$\left.\mathrm{MoClL}_{2}\right]^{+}$, has been carried out by using different ap-

(24) (a) Cacelli, I.; Keogh, D. W.; Poli, R.; Rizzo, A. New J. Chem. 1997, 21 133-135. (b) Cacelli, I.; Keogh, D. W.; Poli, R.; Rizzo, A. J. Phys. Chem., in press.

(25) Poli, R.; Rheingold, A. L. J. Chem. Soc., Chem. Commun. 1990, 552554.

(26) Feng, Q.; Ferrer, M.; Green, M. L. H.; Mountford, P.; Mtetwa, V. S. B. J. Chem. Soc., Dalton Trans. 1992, 1205-1215. 
proaches. The first, perhaps most obvious approach is abstraction of $\mathrm{Cl}^{-}$from the neutral 17-electron (ring)$\mathrm{MoCl}_{2} \mathrm{~L}_{2}$. Given the charged nature of the product and the Lewis acidity of the abstracting reagent, e.g. $\mathrm{AlCl}_{3}$, we were forced to use noncoordinating, polar chlorinated hydrocarbons as solvents. This turned out to be disastrous, leading to $\mathrm{Cl}$ abstraction from the solvent and formation of a cationic 16-electron Mo(IV) product (see eq 4). ${ }^{22}$ Thus, we have learned that the desired 15-electron system has a high radical-type reactivity. A successful strategy for its formation should not involve chlorinated solvents.

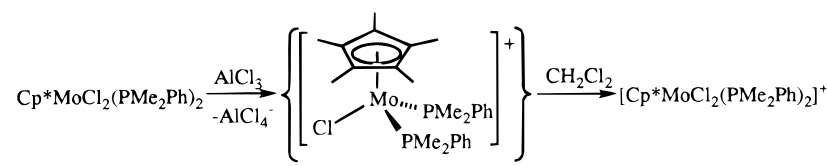

Our next strategy consisted of the decarbonylation of 17-electron [(ring) $\left.\mathrm{MoCl}(\mathrm{CO}) \mathrm{L}_{2}\right]^{+}$precursors. Molecules of this type were not previously known (in fact, no stable mononuclear, paramagnetic $\mathrm{CO}$ derivative of $\mathrm{Mo}$ (III) was previously known), but we found them to be stable and easily accessible by one-electron oxidation of the neutral $\mathrm{Mo}$ (II) precursors (see eq 5; ring $=\mathrm{Cp} *, \mathrm{~L}=\mathrm{PM}_{3}$ or $\mathrm{L}_{2}=$ dppe; ring $=C p, L_{2}=$ dppe). ${ }^{27}$

$$
\begin{aligned}
\text { (ring) } \mathrm{MoCl}(\mathrm{CO}) \mathrm{L}_{2}+ & \mathrm{Cp}_{2} \mathrm{Fe}^{+} \rightarrow \\
{\left[(\text { ring }) \mathrm{MoCl}(\mathrm{CO}) \mathrm{L}_{2}\right]^{+}+\mathrm{Cp}_{2} \mathrm{Fe} } & \text { (5) }
\end{aligned}
$$

Thermal decarbonylation was indeed observed, this being faster for the system with the highest $\mathrm{CO}$ stretching frequency (the Cp-dppe system, complete in $1 \mathrm{~h}$ at $55^{\circ} \mathrm{C}$ in THF), as one would expect for a CO dissociative process. The products of this reaction are a brick-red insoluble Mo(IV) derivative $[\mathrm{CpMoFCl}(\mathrm{dppe})]^{+} \mathrm{PF}_{6}{ }^{-}$and the $\mathrm{Mo}(\mathrm{II})$ compound $\mathrm{CpMoCl}(\mathrm{CO})(\mathrm{dppe})$. The same products are also obtained upon long exposure of the carbonyl precursor to fluorescent light. Recrystallization of the insoluble product from $\mathrm{MeCN}$ gave the diamagnetic 18-electron $\mathrm{MeCN}$ adduct [CpMoFCl(MeCN)(dppe)] ${ }^{+} \mathrm{PF}_{6}{ }^{-}$, whose nature was confirmed by ${ }^{19} \mathrm{~F}-\mathrm{NMR}$ and X-ray crystallography (see Figure 4). ${ }^{27}$ The proposed mechanism for this transformation is illustrated in Scheme 3. These studies demonstrate that the putative 15 -electron $[\mathrm{CpMoCl}$ (dppe) $]^{+}$complex has sufficient Lewis acid reactivity to abstract a fluoride ion from $\mathrm{PF}_{6}{ }^{-}$.

While we still do not have, at this time, what would be the first example of a 15-electron half-sandwich Mo(III) derivative, we are confident that it will be made soon either by decarbonylation of a cationic 17-electron Mo(III)-CO derivative with a counterion such as $\left[\mathrm{B}\left(\mathrm{C}_{6} \mathrm{~F}_{5}\right)_{4}\right]^{-}$ or $\left[\mathrm{B}\left\{3,5-\mathrm{C}_{6} \mathrm{H}_{3}\left(\mathrm{CF}_{3}\right)_{2}\right\}_{4}\right]^{-}$or by one-electron oxidation of the 16-electron $\mathrm{Mo}(\mathrm{II})$ derivatives (ring) $\mathrm{MoClL}_{2}$ that are described in a later section.

\section{Can Stable Half-Sandwich 17-Electron Compounds of Cr(III) Exist?}

We have shown above that 15-electron half-sandwich Mo(III) systems are reactive and unstable relative to 17-

(27) Fettinger, J. C.; Keogh, D. W.; Poli, R. J. Am. Chem. Soc. 1996, 118, $3617-3625$.

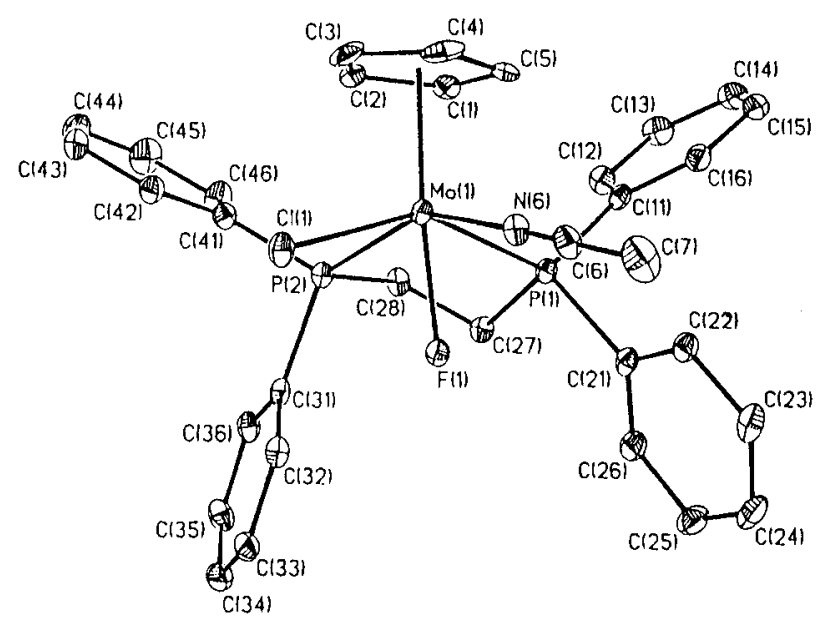

FIGURE 4. X-ray structure of [Cp*MoCIF(MeCN)(dppe)]PF 6 , Reprinted from ref 27. Copyright 1996 American Chemical Society.

Scheme 3

$[\mathrm{CpMoCl}(\mathrm{dppe})(\mathrm{CO})]^{+}$
$-\mathrm{CO} \downarrow \Delta$

$[\mathrm{CpMoCl}(\text { dppe })]^{+}$

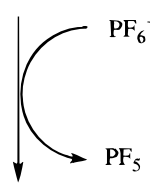

$\mathrm{CpMoClF}(\mathrm{dppe})$

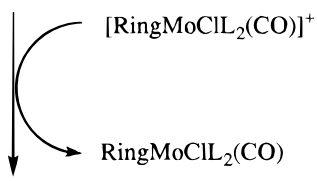

$[\mathrm{CpMoClF}(\mathrm{dppe})]^{+}$

electron systems. We now ask the question: can the corresponding $\mathrm{Cr}$ (III) systems, which are commonly found with a spin quartet 15-electron configuration, be stabilized with a spin doublet 17-electron configuration under any circumstance? Compound $\mathrm{CpCr}\left(\eta^{3}-\mathrm{C}_{3} \mathrm{H}_{5}\right)_{2}$, recently reported by Jolly et al., ${ }^{28}$ is one such example (the allyl ligand is isoelectronic with a XL ligand combination), although the compound is rather unstable and spontaneously decomposes at room temperature. ${ }^{28}$ The reluctance of $\mathrm{CpCrCl}_{2} \mathrm{~L}$ complexes (e.g., $\mathrm{L}=\mathrm{PMe}_{3}$ ) to add another $\mathrm{L}$ ligands cannot be attributed to steric factors, since the similar size V(III) center forms four-legged piano-stool complexes with more crowded ligands, such as $\mathrm{CpV}\left(\mathrm{CH}_{3}\right)_{2-}$ $\left(\mathrm{PEt}_{3}\right)_{2} \cdot{ }^{29}$ Rather, the high energy associated with the electron pairing needed for making a four-legged pianostool geometry [necessary for $\mathrm{d}^{3} \mathrm{Cr}(\mathrm{III})$ but not for $\mathrm{d}^{2} \mathrm{~V}(\mathrm{III})$ ] is the factor to blame. We should therefore look for factors that will reduce the pairing energy or that add to the energetic picture in favor of the 17-electron configuration.

(28) Angermund, K.; Döhring, A.; Jolly, P. W.; Krüger, C.; Romão, C. C. Organometallics 1986, 5, 1268-1269.

(29) Hessen, B.; Lemmen, T. H.; Luttikhedde, H. J. G.; Teuben, J. H.; Petersen, J. L.; Huffman, J. C.; Jagner, S.; Caulton, K. G. Organometallics 1987, 6, 2354-2362. 


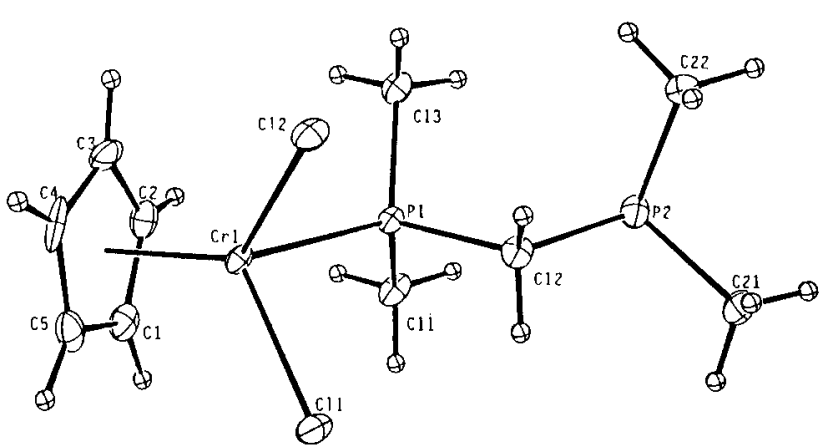

FIGURE 5. Structure of compound $\mathrm{CpCrCl}_{2}\left(\eta^{1}\right.$-dmpm). Reprinted from ref 30. Copyright 1996 American Chemical Society.

An initial approach was based on the introduction of a chelate effect. However, we quickly discovered that compounds $\mathrm{CpCrX}_{2} \mathrm{~L}_{2}\left(\mathrm{X}=\mathrm{Cl}, \mathrm{CH}_{3} ; \mathrm{L}_{2}=\mathrm{dmpm}\right.$, dmpe, dppe) adopt a 15-electron structure with a dangling diphosphine ligand both in the solid state (see Figure 5) and in solution (eq 6).30 The absence of even minor

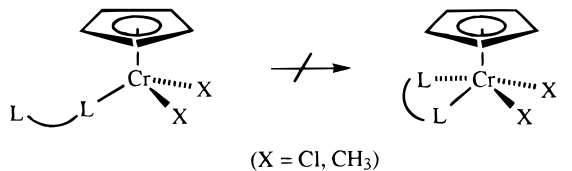

(6)

$\left(\mathrm{X}=\mathrm{Cl}, \mathrm{CH}_{3}\right)$

amounts of 17-electron species in solution is indicated by the absence of sharp EPR resonances at room temperature. Half-sandwich $\mathrm{S}=3 / 2$ 15-electron $\mathrm{Cr}$ (III) compounds can only be observed by EPR spectroscopy at very low temperatures.

A second approach was based on an attempt to reduce the electron pairing energy by careful choice of ancillary ligands. The pairing energy reduction expected on going from dichloro to dimethyl systems proved insufficient. The existence of Jolly's bis-allyl system, ${ }^{28}$ however, indicates the correctness of our strategy. We thus considered using the cyanide ligand, which is a low-electronegative, highly nephelauxetic, sterically undemanding ligand. Indeed, cyanide is known to stabilize high-coordination homoleptic complexes in a low-spin configuration such as $\left[\mathrm{Nb}(\mathrm{CN})_{8}\right]^{5-}$ and $\left[\mathrm{Mo}(\mathrm{CN})_{8}\right]^{]^{-}}$(both $\left.\mathrm{S}=0\right)^{31,32}$ and $\left[\mathrm{Mo}(\mathrm{CN})_{7}\right]^{4-}(\mathrm{S}=1 / 2){ }^{33}$ We thus synthesized compounds $\left[(\text { ring }) \mathrm{Cr}(\mathrm{CN})_{3}\right]^{-}$(ring $=\mathrm{Cp}, \mathrm{Cp} *$ ) by the addition of a $\mathrm{NaCN}$ water solution to [(ring) $\left.\mathrm{CrCl}_{2}\right]_{2}$ (eq 7). Addition of excess $\mathrm{NaCN}$ to the EPR-silent 15-electron anions produces equilibrium amounts of the EPR-active 17-electron $\left[(\text { ring }) \mathrm{Cr}(\mathrm{CN})_{4}\right]^{2-}$ (eq 8, $\mathrm{K}_{\mathrm{eq}}=2.3 \pm 0.1 \mathrm{M}^{-1}$ for $\mathrm{Cp}$ and $(4.4 \pm 0.2) \times 10^{-3} \mathrm{M}^{-1}$ for $\mathrm{Cp}^{*}$ at $\left.298 \mathrm{~K}\right) .^{34}$

$$
\begin{gathered}
{\left[(\text { ring }) \mathrm{CrCl}_{2}\right]_{2}+6 \mathrm{CN}^{-} \rightarrow 2\left[(\text { ring }) \mathrm{Cr}(\mathrm{CN})_{3}\right]^{-}+4 \mathrm{Cl}^{-}} \\
{\left[(\text {ring }) \mathrm{Cr}(\mathrm{CN})_{3}\right]^{-}+\mathrm{CN}^{-} \rightleftarrows\left[(\text { ring }) \mathrm{Cr}(\mathrm{CN})_{4}\right]^{2-}}
\end{gathered}
$$

The 17-electron complexes could not be obtained in the solid state, but they are indefinitely stable in solution.

(30) Fettinger, J. C.; Mattamana, S. P.; Poli, R.; Rogers, R. D. Organometallics 1996, 15, 4211-4222.

(31) Hursthouse, M. B.; Galas, A. M.; Soares, A. M.; Griffith, W. P. J. Chem. Soc., Chem. Commun. 1980, 1167-1168.

(32) Willard, H. H.; Thielke, R. C. J. Am. Chem. Soc. 1935, 57, 2609-2611.

(33) Rossman, G. R.; Tsay, F.-D.; Gray, H. B. Inorg. Chem. 1973, 12, 824829.

(34) Mattamana, S. P.; Poli, R. Organometallics, in press.

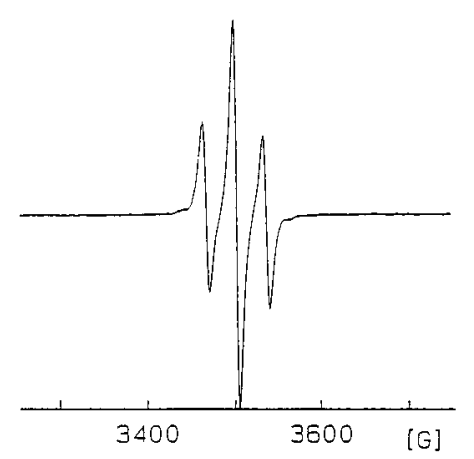

FIGURE 6. EPR spectrum of a solution containing complex $\mathrm{CpCr}(\mathrm{CN})_{2}$ (dmpm).

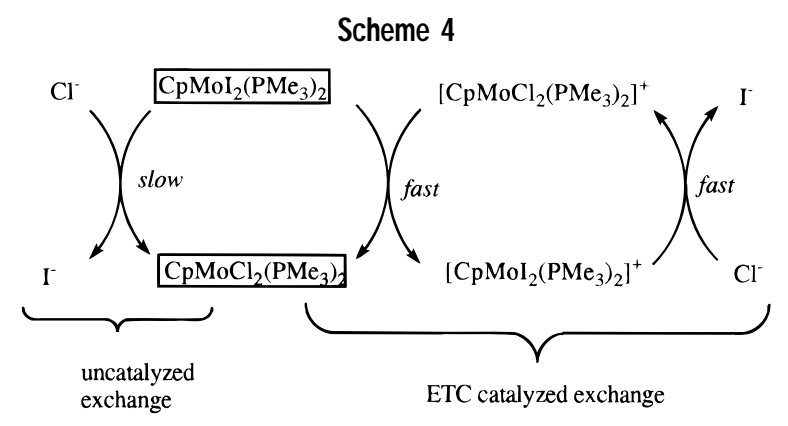

Phosphine-contaning complexes $\mathrm{CpCr}(\mathrm{CN})_{2} \mathrm{~L}_{2}$ could also be observed by EPR (e.g., see Figure 6) as equilibrium species in solution (see eq 9, $\mathrm{L}=\mathrm{PMe}_{3}, \mathrm{PMe}_{2} \mathrm{Ph}$ or $\mathrm{L}_{2}=$ $\eta^{2}$-dmpe). ${ }^{34}$

$$
\left[(\text { ring }) \mathrm{Cr}(\mathrm{CN})_{3}\right]^{-}+\mathrm{L}_{2} \rightleftarrows(\text { ring }) \mathrm{Cr}(\mathrm{CN})_{2} \mathrm{~L}_{2}+\mathrm{CN}^{-}
$$

\section{Electron-Transfer-Catalyzed Exchange on the 17-Electron $\mathrm{CpMoX}_{2} \mathrm{~L}_{2}$ System and Related CpMo(IV) Chemistry}

As mentioned above, the halide exchange reaction on the $\mathrm{CpMoX}_{2}\left(\mathrm{PMe}_{3}\right)_{2}$ system was found to be catalyzed by oxidation. We know that these Mo(III) complexes can be easily and reversibly oxidized to the corresponding 16electron Mo(IV) cations $\left[\mathrm{CpMoX}_{2}\left(\mathrm{PMe}_{3}\right)_{2}\right]^{+} ; 8,9,11$ thus, the possibility of an electron-transfer chain (ETC) ${ }^{35}$ mechanism is evident (Scheme 4). The exchange step on the 16-electron cations should easily occur associatively through saturated 18-electron systems. This result was initially surprising because in typical organometallic systems the slow substitution for saturated, 18-electron configurations is accelerated catalytically by oxidation (or reduction) to odd-electron systems. In our case, for the first time, the exactly opposite order of reactivity occurs: the exchange is faster for even-electron systems (16/18-electron) than for odd-electron ones (either 17/19- or 17/15-electron, vide supra). The corresponding phosphine exchange is not ETC catalyzed because phosphine ligands are uncharged and larger than halide ions; thus, they have no tendency to add to [(ring) MoX $\left.\mathrm{L}_{2}\right]^{+}$and form 18-electron adducts.

The occurrence of the proposed ETC mechanism was proven by a combination of isolation of intermediates, stoichiometric control experiments, and cyclic voltam-

(35) Astruc, D. Angew. Chem, Int. Ed. Engl. 1988, 27, 643-660. 
metric experiments. ${ }^{36}$ Models for the associative Mo(IV) intermediates have been isolated and characterized, e.g. $\mathrm{CpMoCl}_{3}\left(\mathrm{PMe}_{2} \mathrm{Ph}\right)_{2} \cdot{ }^{37}$ The interesting point, of relevance to our discussion here, is that the unsaturated [CpMoX ${ }_{2}$ $\left.\left(\mathrm{PMe}_{3}\right)_{2}\right]^{+}$and the saturated $\mathrm{CpMoX}_{2} \mathrm{Y}\left(\mathrm{PMe}_{3}\right)_{2}(\mathrm{X}, \mathrm{Y}=$ halide) complexes have similar energies, facilitating the rapid exchange in the Mo(IV) manifold. The 16-electron system may be stabilized by steric protection and by the halide ligand lone pairs through $\pi$ bonding. However, all of the examined 16-electron Mo(IV) complexes have a spin triplet ground state. ${ }^{37}$ The effect of the spin change can thus add to and be an important part of the stabilization of the unsaturated system.

\section{Coordinatively Unsaturated (ring)Mo(II) Systems}

Since the pairing energy should be lower in lower oxidation states, we wondered whether we could still observe open-shell configurations and spin change phenomena for organometallic complexes of Mo(II). Half-sandwich Mo(II) derivatives have, almost without exception, an 18electron $\mathrm{CpMoXL}_{3}$ general formula $\mathrm{a}^{38,39}$ and commonly contain $\pi$-acidic ligands such as CO. They can be considered in all respects as classical, "low-valent" organometallics. Compounds without $\mathrm{CO}$ can also be made, however, e.g. $\mathrm{CpMoCl}\left(\mathrm{PMe}_{3}\right)_{3}$ and derivatives. ${ }^{40-42}$ Species with 16 electrons derived by a ligand dissociation are generally high-energy intermediates, e.g. $\mathrm{CpMoCl}(\mathrm{CO})_{2} \cdot{ }^{43}$ However, $\mathrm{CpMoX}(\mathrm{CO})_{2}$ compounds where $\mathrm{X}$ is a good $\pi$-donating and sterically encumbering phosphido or arsenido ligand have been isolated and structurally characterized. 44,45 Another similar example is $\mathrm{Cp} * \mathrm{Mo}\left(\mathrm{PR}_{2}\right)$ $\left(\mathrm{PMe}_{3}\right)_{2}{ }^{46}$ The stability of these diamagnetic compounds can be related to the formal electronic saturation through participation of the $X$ ligand lone pair.

We have been able to obtain the first examples of stable, paramagnetic $(S=1)$, 16-electron organometallic $\mathrm{Mo}$ (II) complexes, (ring) $\mathrm{MoClL}_{2}$ (ring $=\mathrm{Cp}^{*}, \mathrm{~L}_{2}=\left(\mathrm{PMe}_{3}\right)_{2}$, $\left(\mathrm{PMe}_{2} \mathrm{Ph}\right)_{2}$, dppe; ring $=\mathrm{Cp}, \mathrm{L}=\mathrm{PMe}_{2} \mathrm{Ph}$ ) by reduction of $\mathrm{Cp} * \mathrm{MoCl}_{4} / \mathrm{L}$ or $\mathrm{CpMoCl}_{2}\left(\mathrm{PMe}_{2} \mathrm{Ph}\right)_{2}$ in the presence of the required phosphine ligand under $\mathrm{Ar}^{47,48}$ The X-ray struc-

(36) Poli, R.; Owens, B. E.; Linck, R. G. J. Am. Chem. Soc. 1992, 114, 13021307.

(37) Abugideiri, F.; Gordon, J. C.; Poli, R.; Owens-Waltermire, B. E.; Rheingold, A. L. Organometallics 1993, 12, 1575-1582.

(38) Wilkinson, G.; Stone, F. G. A.; Abel, E. W. Comprehensive Organometallic Chemistry; Pergamon: Oxford, U.K., 1982.

(39) Wilkinson, G.; Stone, F. G. A.; Abel, E. W. Comprehensive Organometallic Chemistry II; Pergamon: Oxford, U.K., 1995.

(40) Brookhart, M.; Cox, K.; Cloke, F. G. N.; Green, J. C.; Green, M. L. H.; Hare, P. M.; Bashkin, J.; Derome, A. E.; Grebenik, P. D. J. Chem. Soc., Dalton Trans. 1985, 423-433.

(41) Abugideiri, F.; Kelland, M. A.; Poli, R.; Rheingold, A. L. Organome tallics 1992, 11, 1303-1311.

(42) Abugideiri, F.; Kelland, M. A.; Poli, R. Organometallics 1992, 11, $1311-$ 1318.

(43) Hooker, R. H.; Mahmoud, K. A.; Rest, A. J. J. Chem. Soc., Dalton Trans. 1990, 1231-1241.

(44) Luksza, M.; Kimmer, S.; Malisch, W. Angew. Chem., Int. Ed. Engl. 1983, 22, 416-417.

(45) Gross, E.; Jörg, K.; Fiederling, K.; Göttlein, A.; Malisch, W.; Boese, R. Angew. Chem., Int. Ed. Engl. 1984, 23, 738-739.

(46) Baker, R. T.; Calabrese, J. C.; Harlow, R. L.; Williams, I. D. Organometallics 1993, 12, 830-841.

(47) Abugideiri, F.; Keogh, D. W.; Poli, R. J. Chem. Soc., Chem. Commun. 1994, 2317-2318.

(48) Abugideiri, F.; Fettinger, J. C.; Keogh, D. W.; Poli, R. Organometallics 1996, 15, 4407-4416.

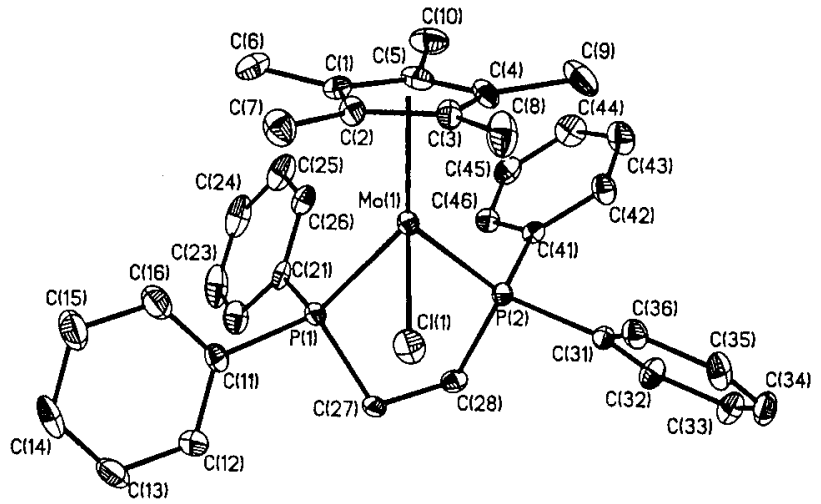

FIGURE 7. X-ray structure of $\mathrm{Cp} * \mathrm{MoCl}(\mathrm{dppe})$. Reprinted from ref 48. Copyright 1996 American Chemical Society.

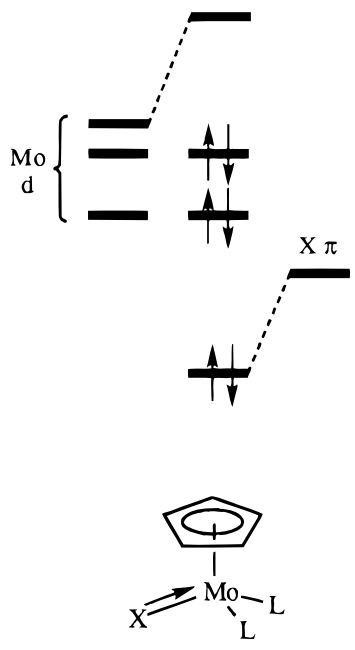

(a)
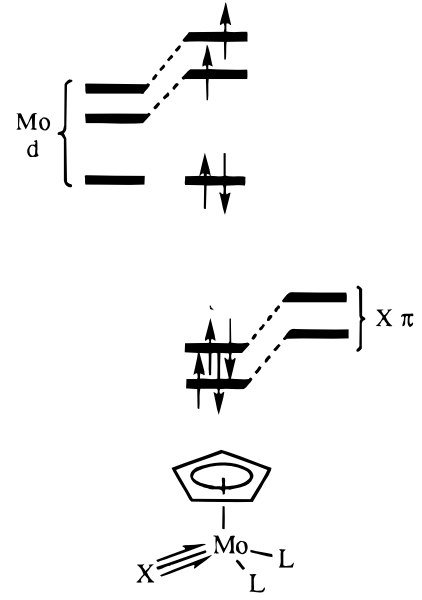

(b)
FIGURE 8. Mo $-\mathrm{X} \pi$ interactions in $\mathrm{C}{ }^{*} \mathrm{MoX}\left(\mathrm{PMe}_{3}\right)_{2}$ for $\mathrm{X}=$ (a) $\mathrm{PPh}_{2}$ and (b) $\mathrm{Cl}$.

ture of $\mathrm{Cp} * \mathrm{MoCl}(\mathrm{dppe})$ is shown in Figure 7. A reason for the paramagnetism of these chloro compounds as opposed to the diamagnetism of the phosphido and arsenido analogues is based on covalent bonding arguments. The $\mathrm{PPh}_{2}$ group is a single-sided $\pi$ donor and is therefore better able to raise the HOMO-LUMO gap (Figure 8a) relative to the double-sided (and weaker) $\pi$ donor chloride ion (Figure 8b). In addition, the chloride ligand is more electronegative than the $\mathrm{PPh}_{2}$ group; thus, the Mo center will have a higher effective positive charge and more contracted orbitals and the pairing energy will consequently be higher for the chloro complex.

A second point of interest concerns the difference between $\mathrm{Mo}$ and $\mathrm{W}$ species. Reduction of $\mathrm{Cp}^{*} \mathrm{WCl}_{4}$ in the presence of $\mathrm{PM} \mathrm{e}_{3}$ affords $\mathrm{Cp} * \mathrm{WClH}\left(\mathrm{CH}_{2} \mathrm{PMe}_{2}\right)\left(\mathrm{PMe}_{3}\right)$, i.e. the product of ortho-metalation of an hypothetical $\mathrm{Cp} * \mathrm{WCl}-$ $\left(\mathrm{PMe}_{3}\right)_{2}$ intermediate. ${ }^{46}$ Compound $\mathrm{Cp} * \mathrm{MoCl}\left(\mathrm{PMe}_{3}\right)_{2}$, however, is stable and does not transform into an orthometalated analogue of the W compound. Similarly, no ortho-metalation process is evident for the $\mathrm{PM}_{2} \mathrm{Ph}$ and dppe derivatives. A greater pairing energy for Mo may be an important factor for rendering the spin triplet 16electron $\mathrm{Cp}^{*} \mathrm{MoClL}_{2}$ system stable with respect to intramolecular oxidative addition processes. 


\section{Is the Spin State Change Slowing the Ligand Addition to $\mathrm{Cp} * \mathrm{MoCl}\left(\mathrm{PMe}_{3}\right)_{2}$ ?}

Unlike many other 16-electron organometallic species, e.g. $\mathrm{M}(\mathrm{CO})_{5}(\mathrm{M}=\mathrm{Cr}, \mathrm{Mo}, \mathrm{W}),{ }^{49} \mathrm{M}(\mathrm{CO})_{4}\left(\mathrm{M}=\mathrm{Ru}^{50} \mathrm{Os}^{51}\right)$, $\mathrm{CpM}(\mathrm{CO})_{3}(\mathrm{M}=\mathrm{V}, \mathrm{Nb}, \mathrm{Ta}),{ }^{52}$ and $\mathrm{CpRh}(\mathrm{CO}),{ }^{53}$ compound $\mathrm{Cp} * \mathrm{MoCl}\left(\mathrm{PMe}_{3}\right)_{2}$ does not add noble gases or THF and does not insert into the $\mathrm{C}-\mathrm{H}$ bonds of the solvent or its own ligands. Such processes would require a costly electron pairing. Both $\mathrm{CO}$ and $\mathrm{N}_{2}$, however, add to the compound to form diamagnetic 18-electron adducts. We have been interested in measuring the relative rates of these two processes because, according to the literature, the addition of $\mathrm{CO}$ and $\mathrm{N}_{2}$ (two isolobal and isosteric substrates) to highly reactive, matrix-isolated 16-electron intermediates, i.e. CpM $(\mathrm{CO})_{3}(\mathrm{M}=\mathrm{V}, \mathrm{Nb}, \mathrm{Ta})^{52}$ and $\mathrm{Cp} * \mathrm{~W}$ $\left(\mathrm{CH}_{3}\right)(\mathrm{CO})_{2},{ }^{54}$ proceeds at similar rates. There is, at most, a factor of 4 in favor of the $\mathrm{CO}$ addition for the $\mathrm{W}$ system. However, $\mathrm{Cp} * \mathrm{MoCl}\left(\mathrm{PMe}_{3}\right)_{2}$ adds $\mathrm{CO} 3$ orders of magnitude faster than $\mathrm{N}_{2}\left(\mathrm{k}_{\mathrm{CO}}=29 \pm 3 \mathrm{M}^{-1} \mathrm{~s}^{-1}\right.$ and $\mathrm{k}_{\mathrm{N} 2}=0.014 \pm$ $0.001 \mathrm{M}^{-1} \mathrm{~s}^{-1}$ at $25^{\circ} \mathrm{C}$ ). The difference in activation is mostly enthalpic, with $\Delta \mathrm{H}^{\ddagger}$ being $5.0 \pm 0.3$ and $14.0 \pm 1.0$ $\mathrm{kcal} / \mathrm{mol}$ for the $\mathrm{CO}$ and $\mathrm{N}_{2}$ additions, respectively. ${ }^{55}$

Theoretical calculations along the ligand addition coordinate have helped clarify the situation (see Figure 9). ${ }^{55}$ In simple terms, addition of a ligand to the spin triplet configuration would generate the unfavorable situation of an 18-electron compound with a semioccupied bonding orbital and a semioccupied antibonding orbital. The system reacts to this stress by trying to eliminate the most weakly bonded ligand. For the $\mathrm{N}_{2}$ addition reaction, such a ligand is $\mathrm{N}_{2}$ itself and the triplet curve is consequently repulsive. For the $\mathrm{CO}$ reaction, on the other hand, other bonds are weaker and lengthen upon approach of the CO ligand, resulting in an attractive spin triplet surface. This phenomenon may also explain other previously observed rapid CO additions involving a spin state change. ${ }^{56-58}$ The spin crossover is therefore at high energy and creates an enthapic barrier to the $\mathrm{N}_{2}$ addition, whereas the barrier to the $\mathrm{CO}$ addition is only due to the initial van der Waals repulsion between the incoming $\mathrm{CO}$ and the coordinated $\mathrm{PH}_{3}$ ligands.

It is important to emphasize that the barrier to the $\mathrm{N}_{2}$ addition is not related to a spin "forbidness", which is known to play a minor role in transition metal complexes in view of the large spin-orbit couplings..$^{59}$ It is rather associated to the structural rearrangement needed to reach the spin crossover point, which can be related to

(49) Wells, J. R.; Weitz, E. J. Am. Chem. Soc. 1992, 114, 2783-2787.

(50) Bogdan, P. L.; Weitz, E. J. Am. Chem. Soc. 1989, 111, 3163-3167.

(51) Bogdan, P. L.; Weitz, E. J. Am. Chem. Soc. 1990, 112, 639-644.

(52) George, M. W.; Haward, M. T.; Hamley, P. A.; Hughes, C.; Johnson, F. P. A.; Popov, V. K.; Poliakoff, M. J. Am. Chem. Soc. 1993, 115, 22862299.

(53) Rest, A. J.; Whitwell, I.; Graham, W. A. G.; Hoyano, J. K.; McMaster, A. D. J. Chem. Soc., Dalton Trans. 1987, 1181-1190.

(54) Virrels, I. G.; George, M. W.; Johnson, F. P. A.; Turner, J. J.; Westwell, J. R. Organometallics 1995, 14, 5203-5208.

(55) Keogh, D. W.; Poli, R. J. Am. Chem. Soc. 1997, 119, 2516-2523.

(56) Wong, K. L. T.; Brintzinger, H. H. J. Am. Chem. Soc. 1975, 97, 51435146

(57) Ryther, R. J.; Weitz, E. J. Phys. Chem. 1991, 95, 9841-9852.

(58) Detrich, J. L.; Reinaud, O. M.; Rheingold, A. L.; Theopold, K. H. J. Am. Chem. Soc. 1995, 117, 11745-11748.

(59) Kavarnos, G. J.; Turro, N. J. Chem. Rev. 1986, 86, 401-449.

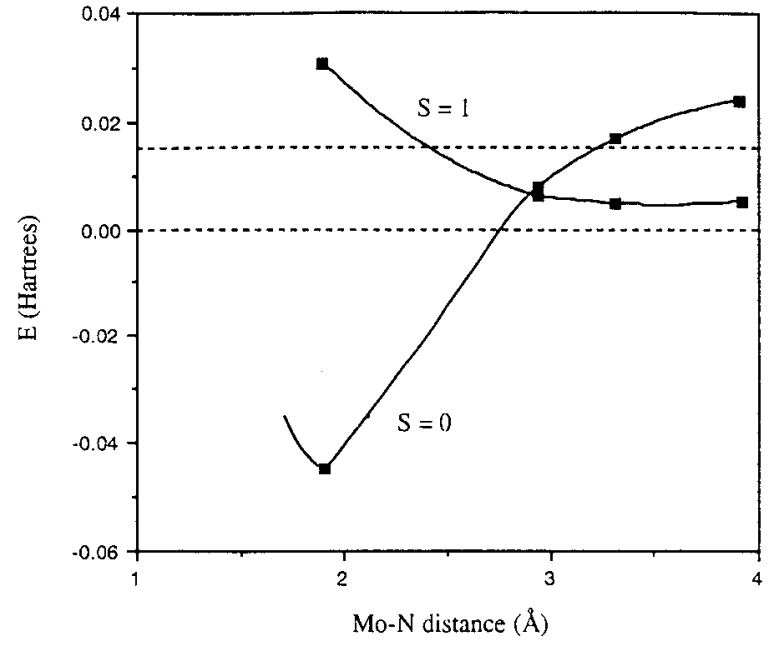

(a)

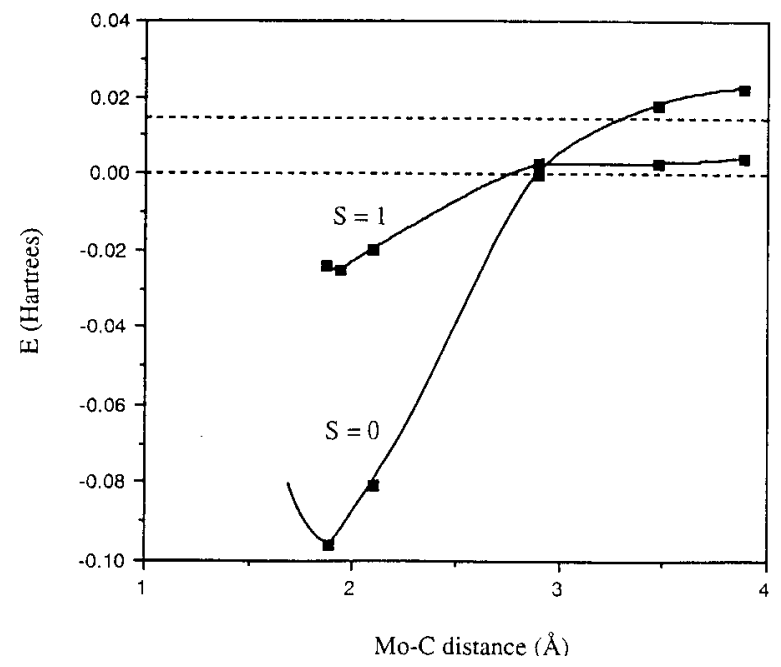

(b)

FIGURE 9. Calculated MP2 reaction coordinate for the addition of $\mathrm{N}_{2}$ (a) or $\mathrm{CO}$ (b) to $\mathrm{Cp} * \mathrm{MoCl}(\mathrm{PMe})_{2}$. The energy axis is normalized relative to the calculated total energy of the two reagents at infinite distance. The upper dashed line corresponds to the energy of ${ }^{1} A^{\prime} \mathrm{CpMoCl}\left(\mathrm{PH}_{3}\right)_{2}$ $+L$ at infinite distance. Reprinted from ref 55. Copyright 1997 American Chemical Society.

the "reorganization energy" as the main factor slowing the rates of intersystem crossing for transition metal complexes. ${ }^{60,61}$

\section{Back to Real Organometallics}

As mentioned in the Introduction, this research was spurred by the idea of carrying out catalytic or stoichiometric processes on organic substrates with radical systems. A simple system that seemed at our reach was the mixed allyl-butadiene complex $\left[\mathrm{CpMo}\left(\eta^{3}-\mathrm{C}_{3} \mathrm{H}_{5}\right)\left(\eta^{4}-\mathrm{C}_{4} \mathrm{H}_{6}\right)\right]^{+}$, which is isoelectronic with the already known ${ }^{3}$ bis(allyl) complex $\mathrm{CpMo}\left(\eta^{3}-\mathrm{C}_{3} \mathrm{H}_{5}\right)_{2}$. It was considered accessible by one-electron oxidation of the parent Mo(II) complex $\mathrm{CpMo}\left(\eta^{3}-\mathrm{C}_{3} \mathrm{H}_{5}\right)\left(\eta^{4}-\mathrm{C}_{4} \mathrm{H}_{6}\right)$. As simple as the latter compound looks, it had apparently not been previously reported, although more complex versions of $\mathrm{Cp}$-allyldiene complexes where the diene and allyl ligands are part

(60) Huheey, J. E.; Keiter, E. A.; Keiter, R. L. Inorganic Chemistry. Principles of Structure and Reactivity, 4th ed.; Harper \& Row: New York, 1993; p 560.

(61) Larsson, S.; Stahl, K.; Zerner, M. C. Inorg. Chem. 1986, 25, 30333037. 
Scheme 5

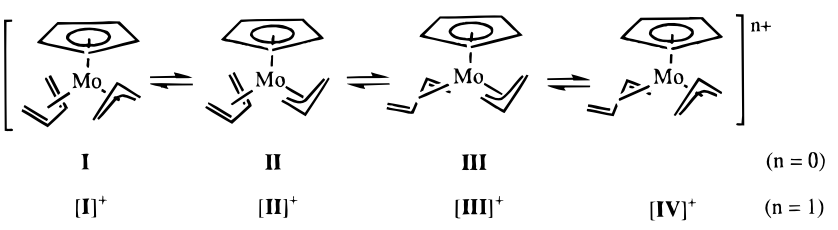

of the same macrocyclic structure are known. ${ }^{62,63}$ We have gained access to this compound by the reaction of $\mathrm{CpMoCl} 2\left(\eta^{4}-\mathrm{C}_{4} \mathrm{H}_{6}\right)$ with allyl Grignard (eq 10). Ferrocenium oxidation provides the stable Mo(III) cationic system as expected, see eq 11.64

$$
\begin{aligned}
\mathrm{CpMoCl}\left(\eta^{4}-\mathrm{C}_{4} \mathrm{H}_{6}\right)+ & \underset{2}{2 \mathrm{C}_{3} \mathrm{H}_{5} \mathrm{MgBr} \rightarrow} \rightarrow \\
& \mathrm{CpMo}\left(\eta^{3}-\mathrm{C}_{3} \mathrm{H}_{5}\right)\left(\eta^{4}-\mathrm{C}_{4} \mathrm{H}_{6}\right)
\end{aligned}
$$

$$
\begin{aligned}
& \mathrm{CpMo}\left(\eta^{3}-\mathrm{C}_{3} \mathrm{H}_{5}\right)\left(\eta^{4}-\mathrm{C}_{4} \mathrm{H}_{6}\right)+\mathrm{Cp}_{2} \mathrm{Fe}^{+} \rightarrow \\
& {\left[\mathrm{CpMo}\left(\eta^{3}-\mathrm{C}_{3} \mathrm{H}_{5}\right)\left(\eta^{4}-\mathrm{C}_{4} \mathrm{H}_{6}\right)\right]^{+}+\mathrm{Cp}_{2} \mathrm{Fe}}
\end{aligned}
$$

Somewhat surprisingly, the neutral Mo(II) complex is obtained in three distinct isomeric forms I, II, and III, all of which have been isolated and independently characterized, whereas the Mo(III) cationic system has been isolated or observed in solution in four different forms, as shown in Scheme 5. Measurements of isomerization rates and equilibria afford the enthal pic picture illustrated in Scheme 6. Two points of interest are the different isomeric preference of $\mathrm{Mo}$ (II) (in favor of I and III) and Mo(III) (in favor of $\left.[\mathrm{II}]^{+}\right)$and the much faster rates of isomerization for the Mo(III) species. In particular, the interconversion of III and II (and of [III] $]^{+}$and [II] $]^{+}$) must necessarily involve dissociation of one arm of the diene ligand, to afford an electronically less saturated intermediate (16electron for $\mathrm{Mo}(\mathrm{II})$, 15-electron for $\mathrm{Mo}(\mathrm{III}))$. A possible reason for the greater accessibility of the less saturated Mo(III) intermediate could be a greater stabilization by regain of electron pairing energy, according to the arguments developed earlier in this Account. The observed trend of isomerization rates suggests that other processes involving intermediates with an open coordination site could also proceed faster for the Mo(III) system relative to the $\mathrm{Mo}(\mathrm{II})$ system. Complex $\left[\mathrm{CpMo}\left(\eta^{3}-\mathrm{C}_{3} \mathrm{H}_{5}\right)\left(\eta^{4}-\right.\right.$ $\left.\left.\mathrm{C}_{4} \mathrm{H}_{6}\right)\right]^{+}$, therefore, should display interesting reactivity

(62) Brammer, L.; Dunne, B. J.; Green, M.; Moran, G.; Orpen, A. G.; Reeve, C.; Schaverien, C. J. J. Chem. Soc., Dalton Trans. 1993, 1747-1759.

(63) Carfagna, C.; Green, M.; Mahon, M. F.; Mclnnes, J. M.; Rumble, S. J.; Woolhouse, C. M. J. Chem. Soc., Dalton Trans. 1996, 3379-3385.

(64) Wang, L.-S.; Fettinger, J. C.; Poli, R. J. Am. Chem. Soc. 1997, 119, 44534464.
Scheme 6

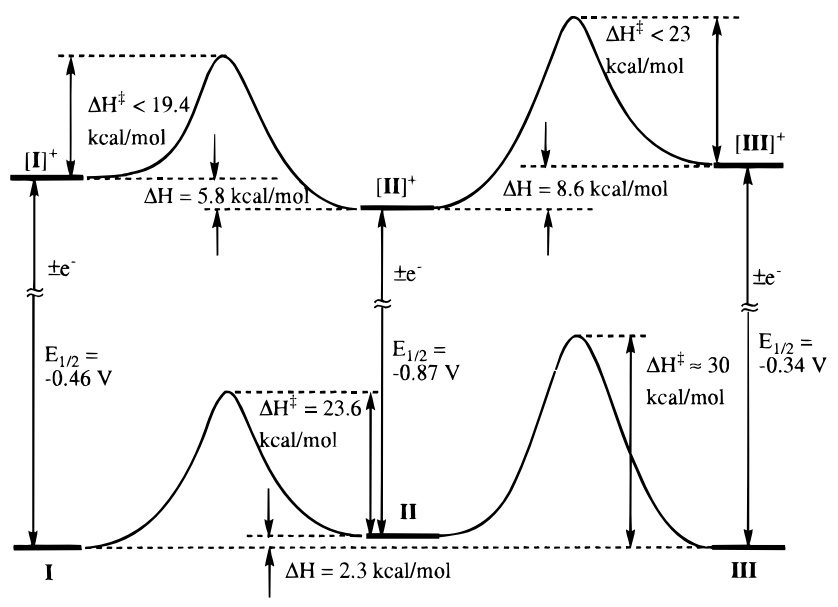

and/or catalytic activity, which are the topics of current investigations.

\section{Conclusions and Outlook}

A spin change can introduce important thermodynamic and kinetic effects not only in reactions of Werner-type compounds but also in middle-valent and low-valent organometallic compounds. We have shown for cyclopentadienylmolybdenum systems that mechanisms of fundamental reactions such as ligand exchange are modified with respect to those of analogous reactions in typical low-valent systems. Processes that are fast in low-valent systems become slow, and others that are slow become fast. It may be possible to tune the properties of these systems to render them useful in synthesis and catalysis. Further investigations in this underdeveloped area of organometallic chemistry will surely be rewarding.

I thank the numerous students and collaborators who have taken part in this project, whose names are shown in the list of references. In particular, I thank Prof. Robert G. Linck, for getting meexcited about kinetics and for getting excited about air-sensitive organometallics, and Drs. Antonio Rizzo and Ivo Cacelli, for getting me excited about ab initio calculations and for getting excited about molecules with more than just a few electrons. I am deeply grateful to the University of Maryland College Park (UMCP) Department of Chemistry and Biochemistry and General Research Board, the Camille and Henry Dreyfus Foundation, the donors of the Petroleum Research Fund, the Alfred P. Sloan Foundation, the Exxon Education Foundation, and the National Science Foundation, for assistance, grants, and awards that have made this research possible at UMCP. 